\title{
IMPLEMENTASI BESARAN BUNGA PEER TO PEER LENDING BERDASARKAN ASAS ITIKAD BAIK DALAM PEMANFAATAN TEKNOLOGI INFORMASI SERTA PENGAWASANNYA
}

\author{
Anita Khoirunisa ${ }^{1}$, Agus Suwandono ${ }^{2}$, Helitha Novianty Muchtar ${ }^{3}$ \\ ${ }^{1}$ Fakultas Hukum, Universitas Padjajaran, email: anita16006@mail.unpad.ac.id \\ ${ }^{2}$ Fakultas Hukum, Ilmu Hukum, Universitas Padjajaran \\ ${ }^{3}$ Fakultas Hukum, Ilmu Hukum, Universitas Padjajaran
}

\section{ABSTRAK}

Pinjam meminjam uang berbasis teknologi informasi atau Peer to Peer Lending ("P2P Lending") merupakan salah satu produk inovasi dari teknologi finansial (fintech) yang bertujuan sebagai alternatif pembiayaan bagi masyarakat. Penyelenggaraan P2P Lending berada di bawah pengawasan OJK yang diatur dalam POJK Nomor 77/POJK.01/2016. OJK menunjuk AFPI sebagai mitra strategis OJK yang berwenang membuat pengaturan pelaksanaan P2P Lending bagi para Penyelenggara yang diakomodasi dalam Pedoman Perilaku yang dibentuk AFPI. Secara singkat, Pedoman Perilaku berisi aturan-aturan yang belum diakomodasi dalam POJK Nomor 77/POJK.01/2016, salah satunya adalah pengaturan tingkat suku bunga pinjaman P2P Lending. Pengaturan suku bunga pinjaman P2P Lending hanya diatur dalam Pedoman Perilaku, namun belum diikuti dengan baik oleh para Penyelenggara karena hingga saat ini masih banyak pelanggaran penetapan suku bunga pinjaman melebihi standar yang telah ditetapkan dengan pemberitahuan informasi suku bunga yang kurang jelas. Oleh karena itu, artikel ini bertujuan untuk menganalisis tentang penerapan pengaturan suku bunga pinjaman P2P Lending yang hanya diatur dalam Pedoman Perilaku. Selain itu, peneliti juga akan menganalisis pemanfaatan teknologi informasi dalam P2P Lending untuk menemukan apakah sejauh ini penyelenggaraan P2P Lending telah sesuai dengan asas itikad baik berdasarkan UndangUndang Nomor 11 Tahun 2008 tentang Informasi dan Transaksi Elektronik. Hasil penelitian hukum ini menunjukkan bahwa OJK diharap mampu untuk mengatur suku bunga pinjaman secara tersendiri agar dapat memberikan kepastian hukum bagi setiap pihak dalam P2P Lending yang berdampak pada pelaksanaan P2P Lending.

\section{ARTICLE INFO}

\section{Kata Kunci:}

Suku Bunga; Teknologi

Finansial; Teknologi

Informasi

\section{Cite this paper:}

Khoirunisa, A.,

Suwandono, A. \&

Muchtar, H. N., 2020.

Implementasi Besaran

Bunga Peer to Peer

Lending Berdasarkan

Asas Itikad Baik dalam

Pemanfaatan Teknologi

Informasi Serta

Pengawasannya. Widya

Yuridika: Jurnal Hukum,

3(1). 


\section{PENDAHULUAN}

Kemajuan teknologi yang cukup pesat telah menghadirkan inovasi-inovasi baru berbasis teknologi informasi yang dapat dimanfaatkan oleh masyarakat. Seiring berjalannya waktu, mulai terdapat berbagai inovasi yang memanfaatkan teknologi informasi, salah satunya adalah teknologi finansial (fintech). Fintech merupakan suatu inovasi di bidang keuangan yang memanfaatkan teknologi informasi. Kehadiran fintech dilatarbelakangi oleh dua faktor, yang pertama merupakan akibat adanya krisis keuangan global yang terjadi pada tahun 2008, yang menunjukkan terdapat kekurangan dalam sistem perbankan tradisional, dan yang kedua adalah kemunculan teknologi baru yang memberikan kemudahan dalam penggunaan, kecepatan, dan biaya layanan keuangan yang lebih rendah. ${ }^{1}$ Kemunculan fintech bertujuan untuk memudahkan masyarakat dalam melakukan transaksi agar lebih cepat dan efisien.

Produk-produk dari fintech hingga saat ini telah banyak yang diluncurkan. Salah satu produk dari fintech adalah Peer to Peer Lending (selanjutnya disebut dengan P2P Lending). P2P Lending merupakan layanan dalam bidang jasa keuangan yang disediakan untuk mempertemukan Pemberi Pinjaman dengan Penerima Pinjaman dalam rangka melakukan perjanjian pinjam meminjam uang melalui sistem elektronik dengan jaringan internet. ${ }^{2}$ Kehadiran P2P Lending dalam sektor jasa keuangan merupakan bentuk alternatif pembiayaan bagi masyarakat yang ingin mendapatkan pinjaman uang melalui platform berbasis teknologi informasi. P2P Lending menawarkan proses yang lebih mudah dibandingkan dengan penawaran pinjaman uang yang ditawarkan oleh sektor perbankan. Langkah-langkah yang mudah untuk mendapatkan pinjaman uang melalui platform P2P Lending, membuat masyarakat cenderung lebih tertarik untuk memanfaatkan platform P2P Lending yang disediakan oleh perusahaan fintech lending guna mendapatkan pinjaman uang. Pemanfaatan teknologi informasi dalam P2P Lending dilaksanakan untuk mengembangkan perdagangan dan perekonomian nasional guna meningkatkan kesejahteraan masyarakat, serta meningkatkan efektivitas dan efisiensi dari pelayanan publik sebagaimana yang dijelaskan dalam Pasal 4 huruf b dan c UndangUndang Nomor 11 Tahun 2008 tentang Informasi dan Transaksi Elektronik (selanjutnya disebut dengan Undang-Undang ITE). ${ }^{3}$

Pelaksanaan P2P Lending yang menggunakan teknologi informasi dalam penyelenggaraannya juga tengah diawasi oleh lembaga-lembaga yang berwenang. Otoritas Jasa Keuangan (selanjutnya disebut dengan 0JK) merupakan salah satu lembaga yang berperan untuk mengatur dan mengawasi pelaksanaan P2P Lending. OJK telah menerbitkan Peraturan Otoritas Jasa Keuangan Nomor 77/POJK.01/2016 tentang Layanan Pinjam Meminjam Uang Berbasis Teknologi Informasi (selanjutnya disebut dengan POJK LPMUBTI) sebagai landasan dalam pelaksanaan P2P Lending. OJK dalam pelaksanaan P2P Lending juga telah menunjuk Asosiasi Fintech Pendanaan Bersama Indonesia (selanjutnya disebut dengan AFPI) sebagai mitra strategis OJK yang berwenang untuk membuat peraturan tambahan bagi para Penyelenggara P2P Lending yang belum diakomodasi dalam POJK Nomor 77/POJK.01/2016. Peraturan tambahan yang bentuk oleh AFPI dituangkan dalam Pedoman Perilaku Pemberian Layanan Pinjam Meminjam

\footnotetext{
${ }^{1}$ Dwi Restu Pratiwi, Pentingnya Perkembangan Financial Technology dalam Mendorog Keuangan Inklusif, hlm. 4.

${ }^{2}$ Pasal 1 angka (3) Peraturan Otoritas Jasa Keuangan Nomor 77/POJK.01/2016 tentang Layanan Pinjam Meminjam Uang Berbasis Teknologi Informasi.

${ }^{3}$ Pasal 4 huruf b dan c Undang-Undang Nomor 11 Tahun 2008 tentang Informasi dan Transaksi Elektronik.
} 
Uang Berbasis Teknologi Informasi secara Bertanggung Jawab (selanjutnya disebut dengan Pedoman Perilaku), dan mencakup berbagai hak dan kewajiban bagi para Penyelenggara dan Pengguna (yang terdiri dari Pemberi Pinjaman dan Penerima Pinjaman), serta peraturan mengenai besaran suku bunga pinjaman maksimal dalam P2P Lending. Pengawasan P2P Lending yang telah dilakukan oleh OJK dan AFPI tidak menghilangkan permasalahan dalam pelaksanaan P2P Lending yang hingga saat ini masih seringkali terjadi, seperti penentuan tingkat suku bunga pinjaman P2P Lending yang melampaui batas, serta pemberitahuan informasi mengenai tingkat suku bunga yang kurang jelas dalam platform P2P Lending yang dapat dimanfaatkan untuk kepentingan kelompok tertentu.

Tingkat suku bunga pinjaman P2P Lending hanya diatur dalam Pedoman Perilaku yang merupakan suatu kebijakan dan diberlakukan untuk kelompok tertentu, yaitu Penyelenggara, dengan berlandaskan pada kesepakatan antar Penyelenggara. Kedudukan Pedoman Perilaku yang bukan merupakan suatu peraturan yang mengikat secara luas atau terkualifikasi sebagai salah satu peraturan perundang-undangan dalam UndangUndang Nomor 12 Tahun 2011 tentang Pembentukan Peraturan Perundang-Undangan menimbulkan pertanyaan seperti apakah Pedoman Perilaku memiliki kedudukan hukum yang pasti, karena hal tersebut akan berdampak pada pemberitahuan informasi mengenai tingkat suku bunga pinjaman P2P Lending yang kurang jelas dan dapat disalahgunakan untuk kepentingan kelompok tertentu. Tujuan Penelitian ini adalah untuk menganalisis penerapan tingkat suku bunga pinjaman P2P Lending yang hanya diakomodasi dalam Pedoman Perilaku, serta menganalisis apakah pelaksanaan P2P Lending telah sesuai dengan asas itikad baik berdasarkan Undang-Undang Nomor 11 Tahun 2008 tentang Informasi dan Transaksi Elektronik, mengingat teknologi informasi digunakan dalam pelaksanaan P2P Lending.

Metode penelitian ini menggunakan metode pendekatan yuridis-normatif, yakni melalui penerapan kaidah-kaidah atau norma-norma dalam hukum positif. ${ }^{4}$ Penelitian hukum ini menggunakan metode yuridis-normatif, karena penelitian hukum ini akan difokuskan pada peraturan perundang-undangan seperti Undang-Undang Nomor 21 Tahun 2011 tentang Otoritas Jasa Keuangan, Undang-Undang Nomor 11 Tahun 2008 tentang Informasi dan Transaksi Elektronik, POJK Nomor 77/POJK.01/2016, Peraturan Pemerintah Nomor 71 Tahun 2019, dan peraturan-peraturan tertulis yang terkait lainnya dalam pengaturan suku bunga dan pelaksanaan P2P Lending.

\section{HASIL DAN PEMBAHASAN}

\section{Pelaksanaan Peer to Peer Lending di Indonesia}

P2P Lending adalah sebuah platform berbasis teknologi untuk mempertemukan secara digital antara Penerima Pinjaman yang membutuhkan modal usaha dengan Pemberi Pinjaman. ${ }^{5}$ Pemberi Pinjaman dengan Penerima Pinjaman dipertemukan melalui wadah yang disediakan oleh Penyelenggara P2P Lending dalam bentuk sebuah aplikasi pinjaman online. Penyelenggaraan P2P Lending merupakan inovasi baru dalam bidang keuangan yang membutuhkan media elektronik dan jaringan internet dalam penggunaannya. Kehadiran P2P Lending merupakan suatu bentuk perubahan dalam layanan pinjam meminjam uang yang semula hanya dapat dilakukan secara konvensional. P2P Lending berfokus pada pinjaman kecil dan mikro, yang mencakup pendanaan untuk

\footnotetext{
${ }^{4}$ Johnny Ibrahim, Teori dan Metodologi Penulisan hukum Normatif, hlm. 295.

${ }^{5}$ Heryucha Romanna Tampubolon, "Seluk-Beluk Peer To Peer Lending Sebagai Wujud Baru Keuangan Di Indonesia”, Jurnal Bina Mulia Hukum, hlm. 191.
} 
usaha kecil dengan masa waktu pinjaman yang singkat. 6 Pemfokusan terhadap pinjaman yang berskala kecil dan mikro membuat masyarakat cenderung memilih P2P Lending untuk mendapatkan pinjaman uang guna memenuhi kebutuhan sehari-hari. Industri P2P Lending sendiri telah menyalurkan dana sejumlah USD 981 juta atau sekitar Rp13,8 triliun pada tahun 2018 dan akan terus meningkat. ${ }^{7}$

Sejarah P2P Lending pertama kali muncul di London, Inggris pada tahun 2005 dengan hadirnya sebuah platform P2P Lending yang bernama Zopa, yang kemudian disusul oleh Amerika Serikat dengan platform P2P Lending yang bernama Prosper dan Lending Club. ${ }^{8}$ Perkembangan teknologi yang cukup pesat dalam bidang keuangan juga telah menghadirkan berbagai platform P2P Lending di Indonesia. Kehadiran P2P Lending sebagai produk fintech di Indonesia dianggap cocok karena tingginya angka penggunaan telepon seluler oleh masyarakat di Indonesia. ${ }^{9}$

Penyelenggaraan P2P Lending di Indonesia dilandasi oleh Peraturan Otoritas Jasa Keuangan Nomor 77/POJK.01/2016 tentang Layanan Pinjam Meminjam Uang Berbasis Teknologi Informasi (POJK LPMUBTI) yang diterbitkan oleh Otoritas Jasa Keuangan (OJK) pada tahun 2016. POJK LPMUBTI terbagi atas beberapa bab yang mengatur tentang ketentuan umum dalam P2P Lending, pengaturan mengenai Penyelenggara dan Pengguna, perjanjian yang timbul antar pihak, mitigasi risiko, tata kelola P2P Lending, edukasi dan perlindungan dalam P2P Lending, tanda tangan elektronik, prinsip dan teknis pengenalan nasabah, larangan dalam P2P Lending, laporan berkala yang wajib disampaikan oleh Penyelenggara, sanksi, ketentuan lain, serta ketentuan peralihan. Penerbitan POJK LPMUBTI merupakan upaya yang dilakukan untuk meminimalisir pelanggaran dalam P2P Lending yang dapat merugikan Pengguna karena minimnya peraturan mengenai $\mathrm{P} 2 \mathrm{P}$ Lending.

P2P Lending memiliki beberapa pihak dalam penyelenggaraannya, yang 3 (tiga) di antaranya terdiri dari Penyelenggara, Pemberi Pinjaman, dan Penerima Pinjaman. Penyelenggara merupakan suatu perusahaan fintech lending terdaftar dan berizin di OJK. Penyelenggara yang dapat beroperasi dalam P2P Lending adalah Penyelenggara yang namanya telah tercantum dalam daftar nama-nama perusahaan yang telah terdaftar dan berizin sebagai perusahaan fintech lending dalam situs OJK. Penyelenggara dalam P2P Lending merupakan pihak yang memiliki platform P2P Lending untuk mempertemukan Pemberi Pinjaman dengan Penerima Pinjaman guna melakukan pinjam meminjam uang. Pemberi Pinjaman tidak dapat berkomunikasi secara langsung dengan Penerima Pinjaman, melainkan hanya dapat mengakses informasi Penerima Pinjaman seperti riwayat kredit dan tujuan peminjaman yang dilakukan oleh Penerima Pinjaman melalui platform yang disediakan oleh Penyelenggara. ${ }^{10}$ Pemberi Pinjaman dalam P2P Lending wajib untuk menyalurkan pinjaman sesuai dengan persyaratan dan ketentuan-ketentuan yang berlaku, serta berhak untuk mendapatkan pengembalian atas pinjaman yang telah diberikan kepada Penerima Pinjaman ditambah dengan bunga atau imbal hasil yang telah ditetapkan di awal pemberian pinjaman, sementara Penerima Pinjaman memiliki hak

\footnotetext{
${ }^{6}$ Limpanadusadee Matugorn dan Li Zhihong, “The Impact of Personal Characteristics on Lender's Trust in Online P2P Lending", Journal of Business and Management, hlm. 49.

${ }^{7}$ Sri Adiningsih, Transformasi Ekonomi Berbasis Digital di Indonesia: Lahirnya Tren Baru Teknologi, Bisnis, Ekonomi, dan Kebijakan di Indonesia, hlm. 95.

${ }^{8}$ Jianqing Huang dan Xiao Liu, "The Analysis of Interest Rate Pricing and Impact on P2P Platform in the Scalper Arbitrage Environment”, Open Journal of Social Sciences, hlm. 166-167.

${ }^{9}$ Thomas Arifin, Berani jadi Pengusaha: Sukses Usaha dan Raih Pinjaman, hlm. 175.

${ }^{10} \mathrm{GAO}$ Ruiqiong dan FENG Junwen, "An Overview Study on P2p Lending”, International Business and Management, hlm. 15.
} 
untuk menerima pinjaman setelah meneyelesaikan prosedur yang telah ditentukan dan memiliki kewajiban untuk mengembalikan pinjaman uang kepada Pemberi Pinjaman.

Pemberi Pinjaman yang akan memberikan pinjaman sejumlah uang kepada Penerima Pinjaman terlebih dulu juga akan diperiksa oleh Penyelenggara dengan melakukan analisis untuk menilaii kelayakan Pemberi Pinjaman sehingga Pemberi Pinjaman yang menjadi investor dalam P2P Lending merupakan Pemberi Pinjaman yang terpercaya dan kredibel untuk melakukan peminjaman sejumlah uang kepada Penerima Pinjaman. Penyelenggara dalam pelaksanaan P2P Lending wajib menggunakan escrow account ${ }^{11}$ dan virtual account ${ }^{12}$ dalam $\mathrm{P} 2 \mathrm{P}$ Lending. ${ }^{13}$ Hal tersebut yang membedakan $\mathrm{P} 2 \mathrm{P}$ Lending dengan pinjaman dalam sektor perbankan, dimana Penyelenggara P2P Lending tidak boleh menghimpun dana, melainkan menggunakan escrow account untuk Penerima Pinjaman dapat melakukan pembayaran dan menyediakan virtual account bagi Pemberi Pinjaman. Penyelenggara juga dilarang untuk bertindak sebagai pemberi dana maupun menghimpun dana dari Pemberi Pinjaman, yang pada intinya menjelaskan bahwa fungsi Penyelenggara hanya sebatas penyedia wadah untuk mempertemukan Pemberi Pinjaman dengan Penerima Pinjaman.

Pelaksanaan P2P Lending didasarkan pada perjanjian yang dibuat antara Penyelenggara dengan Pemberi Pinjaman dan Pemberi Pinjaman dengan Penerima Pinjaman. Pengajuan pinjaman oleh calon Penerima Pinjaman dilakukan hanya dengan penggunaan internet tanpa harus bertatap muka secara langsung dengan Pemberi Pinjaman. Sebelum mengajukan pinjaman sejumlah uang, calon Penerima Pinjaman akan diperiksa terkait kemampuan Penerima Pinjaman dalam melakukan pembayaran. Penerima Pinjaman harus memperhatikan syarat dan ketentuan beserta pasal-pasal dalam perjanjian yang telah dibuat agar tidak menimbulkan masalah yang akan merugikan bagi para pihak di kemudian hari seperti gagal bayar dan wanprestasi.

Perjanjian yang dibuat baik antara Penyelenggara dengan Pemberi Pinjaman maupun Pemberi Pinjaman dengan Penerima Pinjaman dimuat dalam dokumen elektronik. Dokumen elektronik antara Penyelenggara dengan Pemberi Pinjaman paling sedikit wajib memuat nomor perjanjian, tanggal perjanjian, identitas para pihak, ketentuan mengenai hak dan kewajiban para pihak, jumlah pinjaman, suku bunga pinjaman, besarnya komisi, jangka waktu, rincian biaya terkait, ketentuan mengenai denda (jika ada), mekanisme penyelesaian sengketa, dan mekanisme penyelesaian dalam hal Penyelenggara tidak dapat melanjutkan kegiatan operasionalnya. ${ }^{14}$ Selain itu, perjanjian antara Pemberi Pinjaman dengan Penerima Pinjaman paling sedikit memuat nomor perjanjian, tanggal perjanjian, identitas para pihak, ketentuan mengenai hak dan kewajiban para pihak, jumlah pinjaman, suku bunga pinjaman, nilai angsuran, jangka waktu, objek jaminan (jika ada), rincian biaya terkait, ketentuan mengenai denda (jika

\footnotetext{
${ }^{11}$ Escrow account adalah rekening yang dipegang oleh pihak ketiga, yang mengumpulkan, memegang, dan mencairkan dana sesuai dengan kontrak atau kewajiban antara dua pihak (rekening penampungan). Lihat dalam jurnal Edwin S. Mills, “The Functioning and Regulation of Escrow Accounts”, Housing Policy Debate, hlm. 204. ${ }^{12}$ Virtual Account adalah nomor identifikasi pelanggan perusahaan (end user) yang dibuat oleh Bank dan selanjutnya diberikan oleh suatu perusahaan kepada konsumennya sebagai tanda penerimaan. Lihat dalam buku Ahmad Syamil, Pantri Heriyati, dan Marko Hermawan, Perspektif Industri Financial Technology di Indonesia, hlm. 138.

${ }^{13}$ Pasal 24 ayat (1) Peraturan Otoritas Jasa Keuangan Nomor 77/POJK.01/2016 tentang Layanan Pinjam Meminjam Uang Berbasis Teknologi Informasi.

${ }^{14}$ Pasal 19 ayat (2) Peraturan Otoritas Jasa Keuangan Nomor 77/POJK.01/2016 tentang Layanan Pinjam Meminjam Uang Berbasis Teknologi Informasi.
} 
ada), dan mekanisme penyelesaian sengketa. ${ }^{15}$ Semua informasi tersebut harus diketahui oleh para pihak terkait agar tidak menimbulkan kesesatan dalam pelaksanaan P2P Lending.

\section{Penerapan Suku Bunga dalam Peer to Peer Lending}

OJK dalam penyelenggaraan P2P Lending telah menunjuk Asosiasi Fintech Pendanaan bersama Indonesia (AFPI) sebagai mitra strategis 0JK berdasarkan surat Nomor S-5/D/05/IKNB/2019.16 AFPI merupakan sebuah asosiasi yang mewadahi para Penyelenggara dalam penyelenggaraan P2P Lending. AFPI yang merupakan mitra strategis 0JK dalam penyelenggaraan P2P Lending, memiliki kewenangan untuk membuat sebuah aturan yang bernama Pedoman Perilaku Pemberian Layanan Pinjam Meminjam Uang Berbasis Teknologi Informasi secara Bertanggung Jawab (Pedoman Perilaku). Pedoman Perilaku tersebut berisi aturan-aturan tambahan yang belum diakomodasi dalam POJK LPMUBTI dan mengikat bagi para Penyelenggara. Pedoman Perilaku yang dibentuk AFPI mengikat bagi para Penyelenggara karena setiap Penyelenggara P2P Lending wajib terdaftar sebagai anggota asosiasi yang telah ditunjuk OJK, yang dalam hal ini yaitu AFPI. Hal tersebut dilandasi oleh Pasal 48 POJK LPMUBTI yang menjelaskan bahwa Penyelenggara wajib terdaftar sebagai anggota asosiasi yang telah ditunjuk oleh OJK. ${ }^{17}$

Pedoman Perilaku yang dibentuk oleh AFPI Perilaku mengacu kepada 3 (tiga) prinsip dasar, yang di antaranya adalah Pedoman Perilaku tersebut disusun berdasarkan 3 (tiga) prinsip dasar, yaitu transparansi produk dan metode penawaran produk layanan, pencegahan pinjaman berlebih dengan cara mempertimbangkan dan menyesuaikan kemampuan ekonomi Penerima Pinjaman untuk mengembalikan pinjaman, dan penerapan prinsip itikad baik yang harus dilakukan oleh Penyelenggara dengan memperhatikan kepentingan seluruh pihak yang terlibat tanpa merendahkan harkat dan martabat Pengguna. ${ }^{18}$ Pedoman Perilaku juga mengakomodasi peraturan mengenai hak dan kewajiban Penyelenggara, Pemberi Pinjaman, dan Penerima Pinjaman, serta ketentuan besaran suku bunga pinjaman P2P Lending yang tidak diatur dalam POJK LPMUBTI.

Tingkat suku bunga pinjaman P2P Lending yang diatur dalam Pedoman Perilaku yaitu maksimal 0,8\% per hari. ${ }^{19}$ Kepala Bidang Kelembagaan Humas AFPI, Tambur Pardede menjelaskan bahwa besaran bunga maksimal 0,8\% per hari diperuntukan untuk jenis pinjaman multiguna dengan jangka waktu pinjaman kurang dari 1 (satu) bulan. ${ }^{20}$ Pendapat yang disampaikan oleh Kepala Bidang Kelembagaan Humas AFPI tersebut tidak diakomodasi dalam Pedoman Perilaku, karena di dalam Pedoman Perilaku hanya mengakomodasi besaran maksimal 0,8\% per hari tanpa adanya penjelasan lebih lanjut mengenai peruntukan jenis pinjaman. Ketiadaan penjelasan lebih lanjut mengenai

\footnotetext{
${ }^{15}$ Pasal 20 ayat (2) Peraturan Otoritas Jasa Keuangan Nomor 77/POJK.01/2016 tentang Layanan Pinjam Meminjam Uang Berbasis Teknologi Informasi.

${ }^{16}$ Asosiasi Fintech Pendanaan Bersama Indonesia, "AFPI Bekali Calon Penyelenggara Fintech Lending Indonesia", diambil dari https://www.afpi.or.id/detailpressrelease/afpi-bekali-calon-penyelenggara-fintechlending-indonesia.

${ }^{17}$ Pasal 48 Peraturan Otoritas Jasa Keuangan Nomor 77/POJK.01/2016 tentang Layanan Pinjam Meminjam Uang Berbasis Teknologi Informasi.

${ }^{18}$ Pedoman Perilaku, Op.Cit., hlm. 3.

${ }^{19}$ Pedoman Perilaku, Op.Cit., hlm. 7.

${ }^{20}$ IDN Financials, “AFPI Tentukan Bunga Pinjaman Multiguna di Fintech Maksimal 0,8\% per Hari”, diambil dari https://www.idnfinancials.com/id/news/28347/afpi-fintech-lending-larger-day.
} 
peruntukan jenis pinjaman untuk bunga maksimal 0,8\% per hari menunjukan kurangnya keterbukaan informasi biaya termasuk mengenai informasi besaran bunga pinjaman yang jelas dalam P2P Lending yang pada dasarnya sangat penting untuk diketahui oleh para pihak. Penyelenggaraan platform P2P Lending yang tidak aman dapat mengakibatkan risiko kredit yang besar dan menghasilkan bunga pinjaman yang lebih besar dari pinjaman secara tradisional. ${ }^{21}$

Pedoman Perilaku dibentuk berdasarkan kesepakatan antar Penyelenggara yang terdaftar sebagai anggota dari AFPI. Penentuan suku bunga pinjaman dengan maksimal 0,8\% per hari tersebut telah disepakati oleh para Penyelenggara dan sudah semestinya dipatuhi oleh para Penyelenggara, karena Pedoman Perilaku merupakan satu-satunya peraturan yang mengakomodasi besaran suku bunga pinjaman dalam P2P Lending.

Pedoman Perilaku juga mengakomodasi sanksi-sanksi yang dapat dijatuhkan kepada pelanggar atas pelanggaran dalam pelaksanaan P2P Lending. Pelaksanaan penjatuhan sanksi oleh AFPI dilakukan oleh Majelis Etika AFPI. Sanksi-sanksi yang dapat dijatuhkan kepada pelanggar dalam P2P Lending di antaranya adalah: ${ }^{22}$

a. Teguran tertulis;

b. Publikasi nama anggota dan ketentuan yang dilanggar kepada Otoritas Jasa Keuangan dan kepada masyarakat;

c. Pemberhentian sementara dari keanggotaan Asosiasi; dan

d. Pemberhentian tetap dari keanggotaan Asosiasi.

Pedoman Perilaku yang mengatur hak dan kewajiban Penyelenggara, suku bunga pinjaman, sampai dengan sanksi yang dapat dijatuhkan pada pelanggar dalam P2P Lending, tidak menutup kemungkinan bahwa pelanggaran dalam P2P Lending tetap dapat terjadi. Permasalahan dalam P2P Lending hingga saat ini masih seringkali terjadi, termasuk mengenai penerapan suku bunga yang melampaui batas maksimal 0,8\% per hari. Suku bunga pinjaman dalam P2P Lending tergolong lebih tinggi dibandingkan dengan suku bunga yang ditawarkan oleh sektor perbankan, sehingga seharusnya kehadiran P2P Lending tidak boleh merugikan masyarakat. Penetapan batas bunga pinjaman maksimal 0,8\% seharusnya juga dipatuhi oleh Penyelenggara, mengingat apabila terdapat pelanggaran atas pelampauan suku bunga pinjaman P2P Lending yang dilakukan oleh Penyelenggara, maka Penyelenggara tersebut dapat dijatuhkan sanksi oleh Majelis Etika AFPI.

\section{Pelaksanaan Peer to Peer Lending berdasarkan Asas Itikad Baik dalam Pemanfaatan Teknologi Informasi}

P2P Lending merupakan layanan pinjam meminjam uang yang menggunakan sistem elektronik dalam pemanfaatannya. Sistem elektronik dalam P2P Lending digunakan berlandaskan Undang-Undang Nomor 11 Tahun 2008 tentang Informasi dan Transaksi Elektronik. Penyelenggara dalam P2P Lending selain harus terdaftar dan berizin di OJK sebagai perusahaan fintech lending, juga melakukan pendaftaran diri sebagai Penyelenggara Sistem Elektronik pada Kementerian Komunikasi dan Informatika Republik Indonesia (Kemkominfo) dengan menyusun rencana strategis sistem elektronik yang mendukung rencana bisnis Penyelenggara tersebut yang mencakup aspek-aspek seperti manajemen, pengembangan dan perencanaan, operasional teknologi informasi,

${ }^{21}$ GAO Ruiqiong dan FENG Junwen, Loc. Cit.

${ }^{22}$ Asosiasi Fintech Pendanaan Bersama Indonesia (AFPI), Pedoman Perilaku Pemberian Layanan Pinjam Meminjam Uang Berbasis Teknologi Informasi secara Bertanggung Jawab, hlm. 11. 
jaringan komunikasi, pengamanan informasi, rencana pemulihan bencana, layanan pengguna, serta penggunaan pihak penyedia jasa teknologi informasi. ${ }^{23}$ Pendaftaran yang dilakukan Penyelenggara kepada Kemkominfo bertujuan untuk mewujudkan Penyelenggara Sistem Elektronik yang aman dan teredintifikasi oleh pemerintah, terpercaya, dan bertanggung jawab dalam penyelenggaraan sistem elektronik, yang dalam hal ini adalah penyelenggaraan P2P Lending, serta sebagai upaya perlindungan bagi Penyelenggara dalam menyelenggarakan P2P Lending. Kemkominfo bekerja sama dengan 0JK dalam melakukan pengawasan terhadap pelaksanaan P2P Lending dengan cara memantau situs-situs P2P Lending. Kemkominfo dapat memblokir platform P2P Lending yang tidak sesuai dengan aturan yang berlaku dengan arahan dari OJK karena platform P2P Lending menggunakan teknologi informasi sistem elektronik dalam penyelenggaraannya.

Pelaksanaan P2P Lending yang menggunakan sistem elektronik dalam penggunaannya serta jaringan internet dalam pelaksanaannya membuat P2P Lending terkualifikasi sebagai suatu layanan yang memanfaatkan teknologi informasi dan transaksi elektronik. Pemanfaatan teknologi informasi dan transaksi elektronik dalam P2P Lending setidak-tidaknya harus memenuhi asas itikad baik sebagaimana yang diakomodasi dalam Pasal 3 Undang-Undang ITE. Asas itikad baik yang dimaksud dalam Pasal 3 Undang-Undang ITE merupakan landasan bagi para pihak, yang dalam hal ini merupakan pihak dalam P2P Lending, yang digunakan tidak dengan tujuan secara sengaja dan tanpa hak atau melawan hukum mengakibatkan kerugian bagi pihak lain tanpa sepengetahuan pihak yang bersangkutan. ${ }^{24}$ Pemenuhan asas itikad baik merupakan upaya untuk mewujudkan tujuan dari pemanfaatan teknologi informasi dan tranksaksi elektronik yang diakomodasi dalam Pasal 4 Undang-Undang ITE.

Pemenuhan asas itikad baik dalam P2P Lending yang dimaksud dimulai sejak platform tersebut diberikan izin untuk dioperasikan serta saat platform tersebut digunakan oleh masyarakat luas. Penyelenggaraan P2P Lending pada praktiknya hingga saat ini masih menimbulkan berbagai permasalahan, salah satunya adalah pemberitahuan informasi mengenai besaran bunga pinjama yang kurang jelas dalam situs atau platform P2P Lending yang dimiliki oleh Penyelenggara. Pemberitahuan segala informasi terkini mengenai P2P Lending wajib disampaikan oleh Penyelenggara secara jelas, akurat, jujur, dan tidak menyesatkan. ${ }^{25}$ Penyampaian informasi terkini yang dimaksud adalah segala informasi yang penting bagi keberlangsungan pelaksanaan P2P Lending, termasuk penentuan besaran suku bunga serta perubahan terhadap suku bunga pinjaman P2P Lending. Informasi yang disampaikan oleh Penyelenggara P2P Lending setidaknya harus memuat hal-hal seperti: ${ }^{26}$

a. Risiko yang terdapat pada produk dan layanan;

b. Uraian pokok produk yang ditawarkan;

c. Pusat pengaduan; dan/atau

d. Biaya yang timbul sehubungan dengan produk dan layanan.

\footnotetext{
${ }^{23}$ Surat Edaran Otoritas Jasa Keuangan Nomor 18/SEOJK.02/2017 tentang Tata Kelola dan Manajemen Risiko Teknologi Informasi Pada Layanan Pinjam Meminjam Uang Berbasis Teknologi Informasi.

${ }^{24}$ Penjelasan Pasal 3 Undang-Undang Nomor 11 Tahun 2008 tentang Informasi dan Transaksi Elektronik.

${ }^{25}$ Pasal 30 ayat (1) Peraturan Otoritas Jasa Keuangan Nomor 77/POJK.01/2016 tentang Layanan Pinjam Meminjam Uang Berbasis Teknologi Informasi.

${ }^{26}$ Surat Edaran Otoritas Jasa Keuangan Nomor 18/SEOJK.02/2017 tentang Tata Kelola dan Manajemen Risiko Teknologi Informasi Pada Layanan Pinjam Meminjam Uang Berbasis Teknologi Informasi.
} 
Biaya yang timbul sehubungan dengan produk dan layanan mencakup segala bentuk biaya dalam pelaksanaan P2P Lending termasuk biaya bunga pinjaman karena bunga pinjaman timbul ketika terjadi peminjaman sejumlah uang oleh Penerima Pinjaman terhadap Pemberi Pinjaman melalui platform yang telah disediakan oleh Penyelenggara. Pencantuman biaya yang timbul termasuk biaya bunga pinjaman tersebut juga mencakup pemberitahuan lanjut apabila terdapat perubahan suku bunga pinjaman meliputi jumlah biaya yang sebelumnya telah ditetapkan oleh Penyelenggara. Keterbukaan informs mengenai biaya yang timbul sangat penting diketahui oleh para pihak dalam P2P Lending. Ketidakjelasan mengenai berapa besaran bunga pinjaman yang harus ditanggung oleh Penerima Pinjaman seringkali membuat jumlah pinjaman yang harus dikembalikan oleh Penerima Pinjaman melambung tinggi. Pemberitahuan informasi mengenai produk dan layanan yang dimiliki oleh Penyelenggara P2P Lending harus disampaikan dengan jelas agar tidak menimbulkan ketidakjelasan dan kesesatan dalam penyelenggaraan P2P Lending.

Permasalahan mengenai tidak menginformasikan besaran suku bunga dalam platform Peer to Peer Lending secara jelas dapat menjadi faktor tidak terpenuhinya asasasas pemanfaatan teknologi informasi, khususnya asas itikad baik. Padahal pemenuhan asas-asas dalam Undang-Undang ITE dilakukan guna mewujudkan tujuan dari pemanfaatan teknologi informasi dan transaksi elektronik itu sendiri yang diakomodasi dalam dalam Pasal 4 Undang-Undang ITE. Pemenuhan asas itikad baik dalam pemanfaatan teknologi informasi dan transaksi elektronik sangat diperlukan, karena dengan tidak dipenuhinya asas itikad baik khususnya dalam pelaksanaan P2P Lending yang memanfaatkan teknologi informasi dalam penggunaannya, maka akan berdampak pada tidak tercapainya tujuan dari asas kemanfaatan. Asas kemanfaatan yang dimaksud salah satunya adalah pengembangan dalam hal perdagangan dan perekonomian nasional untuk meningkatkan kesejahteraan sebagaimana yang disebutkan dalam Pasal 4 ke-2 Undang-Undang ITE. ${ }^{27}$

Upaya yang dapat dilakukan oleh Penyelenggara P2P Lending dalam memanfaatkan teknologi informasi sesuai dengan asas itikad baik salah satunya adalah dengan mencantumkan segala informasi mengenai produk dan metode penawaran dengan jelas dalam situs P2P Lending yang dimiliki Penyelenggara terkait. Pemberitahuan informasi mengenai produk, biaya, serta metode suku bunga yang digunakan merupakan indikator penting dalam mewujudkan penyelenggaraan P2P Lending yang menjunjung tinggi prinsip keterbukaan dalam P2P Lending.

Selain Penyelenggara yang memiliki kewajiban untuk menginformasikan segala hal penting yang berkaitan dengan pelaksanaan P2P Lending, pemebritahuan segala bentuk informasi mengenai produk dan metode penawaran dengan jelas kepada Pengguna juga dilakukan untuk mewujudkan prinsip dasar dari perlindungan bagi Pemberi Pinjaman dan Penerima Pinjama yang wajib dipenuhi oleh Penyelenggara, yang salah satunya adalah prinsip transparansi. ${ }^{28}$ Transparansi atau keterbukaan merupakan indikator penting dalam penyelenggaraan P2P Lending dan sebagai wujud dalam pemenuhan asas itikad baik dalam pemanfaatan teknologi informasi yang digunakan P2P Lending, karena dengan adanya keterbukaan yang dijunjung tinggi akan membuat kepercayaan terhadap layanan P2P Lending semakin meningkat karena tidak akan merugikan pihak manapun dalam P2P Lending. Pemenuhan asas itikad baik yang dimaksud juga merupakan upaya

\footnotetext{
${ }^{27}$ Pasal 4 angka (2) Undang-Undang Nomor 11 Tahun 2008 tentang Informasi dan Transaksi Elektronik.

${ }^{28}$ Pasal 29 Peraturan Otoritas Jasa Keuangan Nomor 77/POJK.01/2016 tentang Layanan Pinjam Meminjam Uang Berbasis Teknologi Informasi.
} 
untuk menunjukan keamanan dari sebuah platform yang diluncurkan serta keberlangsungan platform P2P Lending terkait, yang mana apabila tidak memenuhi asas itikad baik sebagiamana yang diatur dalam Undang-Undang ITE maka platform tersebut dapat dicabut dan/atau tidak dapat dioperasikan oleh Kemkominfo.

\section{Pengawasan Pelaksanaan Peer to Peer Lending oleh Otoritas Jasa Keuangan}

OJK merupakan lembaga independen yang memiliki peran penting dalam sektor jasa keuangan selain Bank Indonesia. OJK secara garis besar mempunyai fungsi untuk menyelenggarakan sistem pengaturan dan pengawasan yang terintegrasi terhadap keseluruhan kegiatan di dalam sektor jasa keuangan. ${ }^{29}$ Tugas pengaturan dan pengawasan yang dilakukan oleh OJK bertujuan untuk menjadikan OJK sebagai lembaga pengawas dalam sektor jasa keuangan yang dapat dipercaya untuk melindungi kepentingan konsumen dan masyarakat, serta mewujudkan sektor jasa keuangan yang berdaya saing global untuk memajukan kesejahteraan umum. ${ }^{30}$

OJK dalam pelaksanaan P2P Lending bertindak sebagai lembaga yang mengawasi pelaksanaan P2P Lending. OJK juga telah menerbitkan POJK LPMUBTI sebagai payung hukum dalam penyelenggaraan P2P Lending yang mencakup aturan-aturan seperti kriteria Penyelenggara, cara mendaftarkan perusahaan sebagai Penyelenggara, hak dan kewajiban Penyelenggara dengan Pengguna, sampai dengan sanksi apabila terdapat pelanggaran dalam penyelenggaraan P2P Lending. OJK berwenang untuk menjatuhkan sanksi kepada pihak-pihak dalam sektor jasa keuangan yang melanggar peraturanperaturan yang berlaku. Berdasarkan Pasal 9 huruf g Undang-Undang Nomor 21 Tahun 2011 tentang Otoritas Jasa Keuangan (selanjutnya disebut dengan Undang-Undang OJK), menjelaskan bahwa OJK berwenang untuk menetapkan sanksi administratif terhadap pihak-pihak yang melanggar peraturan perundang-undangan di sektor jasa keuangan, maupun memberikan dan/atau mencabut izin usaha, izin orang perorangan, kefektifan pernyataan pendaftaran, surat tanda daftar, persetujuan melakukan kegiatan usaha, pengesahan, persetujuan atau penetapan pembubaran, dan penetapan yang dimaksud dalam peraturan perundang-undangan di sektor jasa keuangan sebagaimana yang telah disebutkan dalam Pasal 9 huruf h Undang-Undang 0JK. ${ }^{31} \mathrm{Hal}$ ini juga mencakup apabila terdapat pelanggaran yang dilakukan dalam P2P Lending, yang membuat 0JK juga memiliki tugas untuk tetap mengawasi pelaksanaan P2P Lending untuk mencegah terjadinya pelanggaran dalam P2P Lending. Pengawasan P2P Lending secara garis besar dilakukan oleh 0JK melalui 3 (tiga) metode, yang di antaranya adalah sebagai berikut. ${ }^{32}$

a. Offsite, yaitu pengawasan yang dilakukan oleh OJK melalui laporan-laporan yang disampaikan oleh Penyelenggara kepada OJK dan juga rencana implementasi host-to-host dengan server Perusahaan;

b. Market Conduct (Semi SRO), yaitu pengawasan yang dilakukan OJK melalui Asosiasi Fintech Pendanaan Bersama Indonesia (AFPI) yang ditunjuk sebagai asosiasi resmi untuk mewadahi Penyelenggara P2P Lending. AFPI memiliki Code of Conduct dan memberikan beberapa pengaturan yang belum diatur 0JK, di antaranya batas maksimal bunga dan tata cara penagihan pinjaman.

\footnotetext{
${ }^{29}$ Kasmir, Bank dan Lembaga Keuangan Lainnya, hlm. 322.

${ }^{30}$ Ibid. hlm. 321.

${ }^{31}$ Pasal 9 huruf g dan h Undang-Undang Nomor 21 Tahun 2011 tentang Otoritas Jasa Keuangan.

${ }^{32}$ Otoritas Jasa Keuangan, "Statistik Fintech Lending Periode Januari 2020", diambil dari https://www.ojk.go.id/id/kanal/iknb/data-dan-statistik/fintech/Pages/Statistik-Fin tech-Lending-Periode-Januari2020.aspx.
} 
c. Onsite, yaitu pengawasan oleh OJK melalui mekanisme pemeriksaan langsung baik yang dilakukan secara rutin maupun sewaktu-waktu.

Penyelenggaraan P2P Lending juga memiliki Standar Prosedur Operasional (SPO) yang diwujudkan dalam kebijakan manajemen resiko setiap platform P2P Lending dan diawasi oleh 0JK. ${ }^{33}$ Pelaksanaan P2P Lending saat ini tengah diawasi oleh OJK, serta AFPI sebagai asosiasi yang telah ditunjuk oleh OJK untuk mewadahi para Penyelenggara P2P Lending. Penunjukan AFPI oleh OJK dilakukan atas permohonan yang diajukan para Penyelenggara dalam P2P Lending. Hal ini didasarkan pada Pasal 21 ayat (1) Peraturan Otoritas Jasa Keuangan nomor 13/P0JK.02/2018 tentang Inovasi Keuangan Digital di Sektor Jasa Keuangan (POJK IKD) yang menjelaskan bahwa Penyelenggara membentuk asosiasi Penyelenggara. ${ }^{34}$ Penyelenggara yang dalam hal ini merupakan Penyelenggara P2P Lending mengajukan permohonan untuk membentuk asosiasi, yaitu AFPI yang kemudian disahkan oleh OJK selaku lembaga pengawas dalam sektor jasa keuangan. OJK juga mewajibkan para Penyelenggara P2P Lending terdaftar sebagai anggota dari asosiasi yang telah ditunjuk oleh OJK. ${ }^{35}$ Pengesahan AFPI sebagai asosiasi yang mengatur dan memiliki kewenangan dalam penyelenggaraan P2P Lending oleh 0JK tidak menghilangkan tanggung jawab OJK sebagai lembaga yang memiliki fungsi pengawasan dalam P2P Lending dan tanggung jawab atas tindakan-tindakan yang dilakukan oleh AFPI termasuk para Penyelenggara yang tergabung menjadi anggota AFPI.

AFPI memiliki kewenangan untuk membuat aturan tambahan dalam P2P Lending yang belum diakomodasi dalam POJK LPMUBTI. Peraturan tambahan tersebut diakomodasi dalam Pedoman Perilaku. Pedoman Perilaku yang merupakan acuan bagi para Penyelenggara dalam rangka menyelenggarakan P2P Lending, mengatur berbagai hak dan kewajiban bagi para Penyelenggara maupun Pengguna, besaran bunga pinjaman dalam P2P Lending, sampai dengan sanksi yang dapat dijatuhkan oleh AFPI melalui Majelis Etika AFPI atas pelanggaran yang dilakukan oleh pelanggar dalam P2P Lending.

Pedoman Perilaku yang dibentuk oleh AFPI merupakan suatu kebijakan yang diberlakukan dan diperuntukan bagi para Penyelenggara P2P Lending. Pedoman Perilaku pada dasarnya tidak memiliki kedudukan hukum sebagaimana jenis-jenis peraturan yang diakomodasi dalam Undang-Undang Nomor 12 Tahun 2011 tentang Pembentukan Peraturan Perundang-Undangan. Peraturan perundang-undangan sendiri menurut A. Hamid S. Attamimi menjelaskan bahwa peraturan perundang-undangan merupakan segala atura hukum yang dibentuk oleh suatu lembaga dalam bentuk dan prosedur tertentu yang disertai sanksi dan mengikat secara umum bagi masyarakat. ${ }^{36}$ Pedoman Perilaku yang merupakan kebijakan yang dibentuk bagi Penyelenggara P2P Lending dibentuk berdasarkan kesepakatan antar Penyelenggara yang merupakan anggota AFPI, sehingga ketentuan tersebut hanya berlaku bagi Penyelenggara yang sepakat dan mengikatkan dirinya yang harus dipatuhi. Pernyataan tersebut menujukan kedudukan Pedoman Perilaku yang tidak memiliki kedudukan hukum yang pasti sehingga belum terdapat kepastian hukum dalam penyelenggaraan P2P Lending, termasuk kepastian

\footnotetext{
${ }^{33}$ Astri Rumondang, dkk., Fintech: Inovasi Sistem Keuangan di Era Digital, hlm. 66.

${ }^{34}$ Pasal 21 ayat (1) Peraturan Otoritas Jasa Keuangan Nomor 13/POJK.02/2018 tentang Inovasi Keuangan Digital di Sektor Jasa Keuangan.

${ }^{35}$ Pasal 48 Peraturan Otoritas Jasa Keuangan Nomor 77/POJK.01/2016 tentang Layanan Pinjam Meminjam Uang Berbasis Teknologi Informasi.

${ }^{36}$ Sony Maulana Sikumbang, Fitriani Ahlan Sjarif, dan M. Yahdi Salampessy, "Modul 1", Pengantar Ilmu Pengetahuan Perundang-undangan, hlm. 8.
} 
hukum mengenai besaran bunga P2P Lending karena hingga saat ini hanya diatur dalam Pedoman Perilaku.

OJK memiliki kewenangan untuk menetapkan peraturan dan keputusan OJK, sebagaimana yang diatud alam Pasal 6 huruf c Undang-Undang Nomor 21 Tahun 2011 tentang Otoritas Jasa Keuangan. ${ }^{37}$ Kewenangan tersebut dapat diwujudkan salah satunya dengan mengatur suku bunga pinjaman P2P Lending untuk meminimalisir permasalahan dalam P2P Lending mengenai penetapan suku bunga pinjaman yang melampaui batas maksimal 0,8\%. Oleh karena itu, pengaturan mengenai suku bunga pinjaman P2P Lending dalam peraturan yang diterbitkan oleh OJK sebagai lembaga pengawas dalam P2P Lending diperlukan untuk meminimalisir permasalahan mengenai pelampauan batas suku bunga pinjaman P2P Lending yang seringkali dimanfaatkan oleh kelompok tertentu, serta hal tersebut merupakan perwujudan dari salah satu tujuan dibentuknya OJK yaitu mampu melindungi kepentingan konsumen dan masyarakat, yang dalam hal ini merupakan para pihak dalam P2P Lending.

\section{PENUTUP}

P2P Lending merupakan layanan pinjam meminjam uang berbasis teknologi yang kian marak digunakan masyarakat untuk memenuhi kebutuhan sehari-hari. P2P Lending memfokuskan pada pinjaman kecil dengan jangka waktu pinjaman relatif singkat. Pelaksanaan P2P Lending saat ini telah diawasi oleh OJK dan AFPI yang merupakan asosiasi yang telah ditunjuk oleh $\mathrm{OJK}$ dan berwenang untuk membuat peraturan tambahan yang belum diatur dalam POJK LPMUBTI, termasuk mengenai tingkat suku bunga pinjaman P2P Lending. Peraturan tersebut diakomodasi dalam Pedoman Perilaku. Tingkat suku bunga pinjaman P2P Lending hingga saat ini hanya diatur dalam Pedoman Perilaku yang tidak memiliki kekuatan hukum dan pemberitahuan informasi mengenai tingkat suku bunga dalam situs P2P Lending yang kurang jelas dikhawatirkan dapat disalahgunakan oleh kelompok tertentu. Oleh karena itu, otoritas diharapkan mampu untuk mengatur pelaksanaan P2P Lending lebih komprehensif termasuk mengatur mengenai tingkat suku bunga pinjaman P2P Lending agar terciptanya kepastian hukum dan sebagai upaya untuk mengurangi pelanggaran atas penetapan suku bunga pinjaman P2P Lending yang melampaui batas maksimal.

\section{DAFTAR PUSTAKA}

\section{Peraturan Perundang-Undangan}

Undang-Undang Nomor 21 Tahun 2011 tentang Otoritas Jasa Keuangan.

Undang-Undang Nomor 11 Tahun 2008 tentang Informasi dan Transaksi Elektronik.

Peraturan Otoritas Jasa Keuangan Nomor 77/P0JK.01/2016 tentang Layanan Pinjam Meminjam Uang Berbasis Teknologi Informasi.

Surat Edaran Otoritas Jasa Keuangan Nomor 18/SEOJK.02/2017 tentang Tata Kelola dan Manajemen Risiko Teknologi Informasi Pada Layanan Pinjam Meminjam Uang Berbasis Teknologi Informasi.

\section{Buku}

Adiningsih, Sri. (2019). Transformasi Ekonomi Berbasis Digital di Indonesia: Lahirnya Tren Baru Teknologi, Bisnis, Ekonomi, dan Kebijakan di Indonesia. Jakarta: PT Gramedia Pustaka Utama.

\footnotetext{
${ }^{37}$ Pasal 6 Undang-Undang Nomor 21 Tahun 2011 tentang Otoritas Jasa Keuangan.
} 
Arifin, Thomas. (2018). Berani jadi Pengusaha: Sukses Usaha dan Raih Pinjaman. Jakarta: PT Gramedia Pustaka Utama.

Ibrahim, Johnny. (2006). Teori dan Metodologi Penulisan hukum Normatif. Malang: Bayumedia Publishing.

Kasmir. (2014). Bank dan Lembaga Keuangan Lainnya. Jakarta: PT Raja Grafindo.

Rumondang, Astri, dkk. (2019). Fintech: Inovasi Sistem Keuangan di Era Digital. Medan: Yayasan Kita Menulis.

Syamil, Ahmad, Pantri Heriyati, dan Marko Hermawan. (2020). Perspektif Industri Financial Technology di Indonesia. Jawa Timur: Qiara Media.

\section{Artikel Jurnal Lewat Website}

Huang, Jianqing dan Xiao Liu. (2018). The Analysis of Interest Rate Pricing and Impact on P2P Platform in the Scalper Arbitrage Environment. Open Journal of Social Sciences, 6, 166-179. Retrieved from https://pdfs.semanticscholar.org/ 3b85/f91cd587cec3b428be7 8f9264c58dbb47 890.pdf

Matugorn, Limpanadusadee dan Li Zhihong. (2017). The Impact of Personal Characteristics on Lender's Trust in Online P2P Lending. Journal of Business and Management, 19(11), 48-54. Retrieved from http://www.iosrjournals.org/iosr$\mathrm{jbm} /$ papers/Vol19-issue11/Version-7/H1911 074854 .pdf

Mills, Edwin S. (1998). The Functioning and Regulation of Escrow Accounts. Housing Policy Debate. 5(2), 203-218. Retrieved from https://www.innovatio ns.harvard.edu/sites/default/files/hpd 0502 mills.pdf

Pratiwi, Dwi Restu. (2018). Pentingnya Perkembangan Financial Technology dalam Mendorong Keuangan Inklusif. Buletin APBN. 3(15), 3-8. Retrieved from https: //berkas.dpr.go.id/puskajia nggaran/buletin-apbn/public-file/buletin-apbnpublic- 64.pdf

Ruiqiong, GAO dan FENG Junwen. (2014). An Overview Study on P2p Lending. International Business and Management. 8(2), 14-18. Retrieved from https://pdfs.semanticscholar.org/abcf/2 8ac799f85d724b22e6df61f12c5046228e1.pdf

\section{Website}

Asosiasi Fintech Pendanaan Bersama Indonesia (AFPI). (2019). AFPI Bekali Calon Penyelenggara Fintech Lending Indonesia. Diambil Februari 24, 2020, dari https://www.afpi.or.id/detail pressrelease/afpi-bekali-calon-penyelenggarafintech-lending-indo nesia

Asosiasi Fintech Pendanaan Bersama Indonesia (AFPI). (2019). Pedoman Perilaku Pemberian Layanan Pinjam Meminjam Uang Berbasis Teknologi Informasi secara Bertanggung Jawab. Diambil Febrruari 24, 2020, dari https://www.afpi.or.id/detailsnews/pedoman-perilaku

IDN Financials. (2019). AFPI Tentukan Bunga Pinjaman Multiguna di Fintech Maksimal 0,8\% per Hari. Diambil Februari 24, 2020, dari https://www.idnfinancials.com/id/news/ 28347/af pi-fintech-lending-largerday

Otoritas Jasa Keuangan. (2019). Statistik Fintech Lending Periode Januari 2020. Diambil Februari 24, 2020, dari https://www.ojk.go.id/id/kanal/iknb/data-danstatistik/fintech/Pages/Statistik-Fin tech-Lending-Periode-Januari-2020.aspx 
Widya Yuridika: Jurnal Hukum, Volume 3 / Nomor 1 / Juni 2020

Sony Maulana Sikumbang, Fitriani Ahlan Sjarif, dan M. Yahdi Salampessy. (2015). Modul 1. Pengantar Ilmu Pengetahuan Perundang-undangan. Diambil Februari 25, 2020, dari http://repository.ut.ac .id/4111/1/HKUM4403-M1.pdf 